\author{
Anna Maria Barańska \\ ORCID: 0000-0001-7312-3587 \\ Uniwersytet Jagielloński
}

DOI: $10.19195 / 1733-5779.25 .6$

\title{
Nienależyte umocowanie pełnomocnika jako przesłanka nieważności postępowania
}

\section{JEL Classification: K40}

Słowa kluczowe: pełnomocnik, nieważność postępowania, art. 379 k.p.c., nieprawidłowe umocowanie

Keywords: proxy, a nullity of the proceeding, art. 379 of the Polish Code of Civil Procedure, improper empower

\begin{abstract}
Abstrakt: Artykuł traktuje o nieważności postępowania ze względu na występowanie w sprawie nieprawidłowo umocowanego pełnomocnika w rozumieniu art. 379 pkt 2 k.p.c. oraz art. 401 pkt 2 k.p.c. Przesłanka ta w praktyce sprawia wiele trudności, albowiem nie ma przepisu, który zezwalałby wprost na zatwierdzenie przez stronę czynności procesowych podjętych przez nieprawidłowo umocowanego pełnomocnika. Nie zawsze jednak kategoryczne odrzucenie takiej możliwości wydaje się słuszne i uzasadnione. W opracowaniu zwrócono uwagę, że nie można utożsamiać przypadku, w którym jako pełnomocnik staje osoba w ogóle niemogąca pełnić takiej funkcji, z sytuacją, w której pełnomocnik jest wyłącznie nieprawidłowo umocowany. Pierwsza z opisanych sytuacji bowiem zawsze skutkuje nieważnością postępowania, druga zaś może podlegać sankcji na skutek następczego zatwierdzenia dokonanych czynności procesowych przez osobę do tego uprawnioną. Na zakończenie poruszono kwestię dopuszczalności zgłaszania takowego naruszenia przez każdą ze stron postępowania oraz ich interesu prawnego w takim działaniu. Omówienie ma na celu wskazanie różnic pomiędzy poszczególnymi przypadkami oraz podjęcie próby określenia możliwych sposobów postępowania w razie ich zaistnienia.
\end{abstract}

\section{The nullity of the proceeding in case of representative improperly empowered}

Abstract: The paper covers a nullity of the proceedings arising out of case where the representative of a party was not duly empowered within the meaning of the article 379 point 2 . and the article 401 point 2. of the Polish Code of Civil Procedure. In practice this premise causes a lot of difficulties due to missing law permitting straight approval of procedural actions performed by a representative improperly empowered - having considered that categorical rejection of such an 
opportunity not always seems to be the right and justified decision. In the contents of the paper attention is paid to the fact that it is incorrect to equate the case in which a person was not able to perform as a proxy with the situation where the representative was improperly empowered. The first case entails the invalidity of the proceedings, while the latter may be subject to legitimization, as a result of a subsequent confirmation of the procedural actions taken by an empowered person. Finally, the issue of the admissibility of reporting such a violation by a party to the proceedings as well as their legal interest in such an action is raised. Such an analysis will permit to indicate the differences between cases along with an attempt to indicate a possible procedure when it occurs.

\section{Wstęp}

O nieważności postępowania stanowi art. 379 k.p.c. ${ }^{1}$, który w sposób wyczerpujący wymienia sytuacje, jakie winne być z urzędu brane pod rozwagę przez sąd. Bez znaczenia pozostaje wtedy fakt, że ponownie przeprowadzone postępowanie doprowadzi do takiego samego rozstrzygnięcia. $Z$ powodu bezwzględnego charakteru przyczyn nieważności nie ma również znaczenia, czy strona wiedziała o błędach sądu i czy mogła je wytknąć w toku postępowania przed sądem I instancji. Co jednak warte podkreślenia, orzeczenie dotknięte nieważnością wywołuje skutki prawne, dopóki nie zostanie zaskarżone, a zatem w Kodeksie postępowania cywilnego nie ma instytucji nieważności postępowania bądź też orzeczenia z mocy samego prawa.

Zgodnie z brzmieniem art. 379 pkt 2 k.p.c. jedną z przyczyn nieważności postępowania jest nieprawidłowe umocowanie pełnomocnika działającego w sprawie. Przesłanka ta w praktyce sprawia wiele trudności, albowiem w Kodeksie postępowania cywilnego nie ma przepisu, który zezwalałby wprost na zatwierdzenie przez stronę czynności procesowych podjętych przez nieprawidłowo umocowanego pełnomocnika.

Dodatkowo sytuację komplikuje brzmienie art. 401 pkt 2 k.p.c., zgodnie z którym można żądać wznowienia postępowania z powodu nieważności, jeśli strona nie była należycie reprezentowana. W konsekwencji należy rozróżnić postępowanie, w którym udział bierze pełnomocnik niemogący w ogóle pełnić takowej funkcji, od postępowania, w którym uczestniczy pełnomocnik spełniający wymagania określone $\mathrm{w}$ art. 87 k.p.c., ale niebędący prawidłowo umocowany. Zagadnienie to nie jest w orzecznictwie Sądu Najwyższego nowe, albowiem już w okresie międzywojennym było ono przedmiotem jego rozważań ${ }^{2}$. Stanowisko Sądu Najwyższego na przestrzeni lat i obowiązujących przepisów ulegało ciągłej modyfikacji i ewolucji.

${ }^{1}$ Ustawa z dnia 17 listopada 1964 roku — Kodeks postępowania cywilnego (tekst jedn. Dz.U. z 2016 r. poz. 1822).

2 Wyrok Sądu Najwyższego z dnia 24 sierpnia 1937 roku, sygn. akt C I 2382/36, Zb. Urz. 1938, poz. 282. 


\section{Pełnomocnictwo osoby nieposiadającej odpowiednich kwalifikacji}

Może zdarzyć się, że w postępowaniu rolę pełnomocnika procesowego będzie pełnić osoba, która nie posiada do tego kwalifikacji przedstawionych w art. 87 k.p.c. Przedstawione tam wyliczenie ma bowiem charakter wyczerpujący, a zatem osoby spoza określonego w nim kręgu nie mogą zostać skutecznie ustanowione pełnomocnikiem procesowym. Na jego podstawie możliwe jest zasadniczo wyodrębnienie trzech grup takich osób (podmiotów). Do pierwszej należą adwokaci i radcy prawni oraz - w sprawach z zakresu własności przemysłowej - rzecznicy patentowi, a w sprawach dotyczących restrukturyzacji i upadłości - osoby mające licencję doradcy restrukturyzacyjnego; do drugiej — osoby sprawujące zarząd majątkiem lub interesami strony oraz pozostające ze stroną $\mathrm{w}$ stałym stosunku zlecenia; do trzeciej zaś osoby, które ze względu na osobisty lub procesowy stosunek do stron są lub mogą być bezpośrednio albo pośrednio zainteresowane wynikiem sprawy ${ }^{3}$.

Rozważenia zatem wymaga kwestia, czy przedsięwzięte przez takiego pełnomocnika czynności procesowe mogą zostać następczo zatwierdzone przez osobę do tego uprawnioną, a w konsekwencji zapobiec konieczności ponownego przeprowadzenia postępowania. W związku z brakiem jednoznacznych uregulowań prawnych problem ten stał się przedmiotem rozważań Sądu Najwyższego już w uchwale z dnia 20 grudnia 1968 roku $^{4}$, w którym podkreślono, że skuteczność prawna czynności procesowych dokonanych przez osobę, która nie może być pełnomocnikiem procesowym, zależy od ich zatwierdzenia przez zainteresowaną stronę. Sąd Najwyższy stwierdzil, że w razie działania osoby trzeciej, która nie może być pełnomocnikiem, dochodzi do klasycznego działania osoby trzeciej bez zlecenia, a zatem ważność takowych czynności zależy od zatwierdzenia ich przez osobę uprawnioną. Zatwierdzenie zaś jest aktem jednostronnym, który nie wymaga przyjęcia ani akceptacji ze strony przeciwnika procesowego i może nastąpić w każdym czasie. Podobnie należy traktować sytuację, gdy osoba trzecia działa z upoważnienia osoby zainteresowanej, ale nie może być pełnomocnikiem w świetle przepisów prawa. Brak ten sąd winien brać pod uwagę z urzędu i dążyć do jego usunięcia poprzez wezwanie zainteresowanej strony do zatwierdzenia czynności dokonanych przez osobę trzecią. Stanowisko to zostało podtrzymane przez Sąd Najwyższy w uchwale z dnia 18 września 1992 roku, gdzie dodatkowo zauważono, że zgodnie $\mathrm{z}$ treścią art. 97 k.p.c. strona może zawsze potwierdzić

3 J. Gudowski, Komentarz do art. 87 k.p.c., [w:] Kodeks postępowania cywilnego. Komentarz, t. 1. Postępowanie rozpoznawcze, red. T. Ereciński, Warszawa 2016, s. 370-403.

4 Uchwała Sądu Najwyższego z dnia 20 grudnia 1968 roku, sygn. akt III CZP 93/68, OSNC 1969, nr 7-8 s. 129. 
czynności procesowe dokonane w jej imieniu przez osobę działającą bez żadnego umocowania 5 .

Warto przytoczyć również wyrok Sądu Najwyższego z dnia 13 marca 1991 roku $^{6}$, w którym zaznaczono, iż sam fakt, że pełnomocnik procesowy jednej ze stron nie należał do wymienionego w art. $87 \S 1$ k.p.c. grona osób, nie daje jeszcze podstawy do przyjęcia, że w sprawie zachodzi nieważność postępowania. Taki brak prowadzi bowiem do nieważności postępowania wyłącznie wtedy, gdy w jego konsekwencji dochodzi do istotnego naruszenia praw procesowych strony, godzącego w jej możliwość prawidłowego powzięcia i wyrażenia woli.

Wskazane stanowisko znalazło w doktrynie zarówno zwolenników, jak i krytyków. Jego przeciwnicy wskazywali przede wszystkim, że dopuszcza ono zmianę ustawowego kręgu osób mogących być pełnomocnikami przy pomocy woli stron.

Początek odmiennego kierunku orzecznictwa jest związany z wyrokiem Sądu Najwyższego z dnia 20 sierpnia 2001 roku, choć w rzeczywistości nie jest to pierwszy wyrok Sądu Najwyższego, w którym podniesiono, że nie jest dopuszczalne potwierdzenie przez stronę czynności dokonanych przez osobę niemogącą być w ogóle pełnomocnikiem ${ }^{7}$. W wyroku z dnia 20 sierpnia 2001 roku Sąd Najwyższy stwierdził, że: „Występowanie w sprawie w charakterze pełnomocnika osoby, która nim nie może być, oznacza brak należytego umocowania pełnomocnika, a tym samym zawsze prowadzi do nieważności postępowania (art. 379 pkt 2 k.p.c.)" 8 . W jego uzasadnieniu wskazano, że art. 97 k.p.c. dotyczy wyłącznie ściśle określonej sytuacji procesowej i nie może być wykładany rozszerzająco. Zdaniem Sądu Najwyższego nie można również uznać, że dopuszczalność potwierdzania czynności nienależycie umocowanego pełnomocnika wynika z istoty pełnomocnictwa. Godzi to bowiem w istotę uchybień powodujących nieważność postępowania, które przynoszą taki skutek bez względu na to, jaki miały wpływ na tok postępowania i prawidłowość rozstrzygnięcia. Pogląd ten należy uznać za dominujący.

Z powyższą tezą nie zgodził się jeszcze Sąd Najwyższy w postanowieniu z dnia 18 marca 2003 roku$^{9}$. W ustalonym w sprawie stanie faktycznym pełnomocnikiem uczestnika postępowania o podział majątku wspólnego już po ustaniu wspólności

${ }^{5}$ Uchwała Sądu Najwyższego z dnia 18 września 1992 roku, sygn. akt III CZP 112/92, OSNC 1993, nr 5, s. 75.

6 Wyrok Sądu Najwyższego z dnia 13 marca 1991 roku, sygn. akt I CR 484/90, OSNC 1992, nr 7-8, s. 138.

7 Wyrok Sądu Najwyższego z dnia 29 września 1998 roku, sygn. akt II CKN 529/98, LEX nr 1214908, tak też Wyrok Sądu Najwyższego z dnia 10 sierpnia 2000 roku, sygn. akt IV CKN 1137/00, LEX nr 530702.

8 Wyrok Sądu Najwyższego z dnia 20 sierpnia 2001 roku, sygn. akt I PKN 586/00, OSNP 2003, nr 14 s. 335.

9 Postanowienie Sądu Najwyższego z dnia 18 marca 2003 roku, sygn. akt IV CKN 1856/00, LEX nr 109422. 
majątkowej małżonków był radca prawny, który w tym czasie nie mógł brać w nim udziału jako pełnomocnik. Sąd Najwyższy przyjął jednak, że postępowanie nie mogło zostać uznane za nieważne tylko z tego powodu, albowiem reprezentowany uczestnik w dalszej fazie toczącego się postępowania potwierdził wszelkie czynności dokonane przez wspomnianego radcę prawnego. Na uzasadnienie swojego stanowiska przywołał zaś orzeczenie Sądu Najwyższego z dnia 18 września 1992 roku.

Powyższe orzeczenie należy jednak uznać za swoisty wyłom w kształtującej się linii orzeczniczej Sądu Najwyższego. Już bowiem w uchwale z dnia 28 lipca 2004 roku $^{10}$ Sąd Najwyższy ponownie podkreślił, że występowanie w sprawie w charakterze pełnomocnika strony osoby, która nie może nim być, oznacza brak należytego umocowania, co powoduje nieważność postępowania, a uchybienie to nie może być usunięte $\mathrm{w}$ drodze zatwierdzenia przez stronę czynności dokonanych przez tę osobę. Zauważył przy tym, że art. 97 k.p.c. może znaleźć zastosowanie wyłącznie gdy dana osoba co do zasady mogłaby być pełnomocnikiem, ale nie przedstawiła w danej sprawie stosownego pełnomocnictwa. Nie odnosi się zatem do sytuacji, w której czynność procesowa została podjęta przez osobę działającą na podstawie pełnomocnictwa udzielonego jej przez stronę, lecz niemogącą być pełnomocnikiem. Wyjaśnił również, że kwestię tego, kto i w jakich sprawach może być pełnomocnikiem procesowym strony, określa ustawa, a zatem strona swoim działaniem nie może tego zmieniać. Zauważył przy tym:

$\mathrm{Z}$ istoty pełnomocnictwa nie wynika bowiem dopuszczalność potwierdzenia czynności nienależycie umocowanego pełnomocnika, jeżeli polegało ono na ustanowieniu pełnomocnikiem osoby, która pełnomocnikiem być nie może, chodzi bowiem w tym wypadku nie o nienależyte umocowanie pełnomocnika polegające na braku pełnomocnictwa, ale na umocowaniu pełnomocnikiem osoby, która $\mathrm{z}$ woli ustawy nie może być pełnomocnikiem. Zatwierdzenie takie nie usuwałoby braku istnienia pełnomocnictwa, bo takie strona udzieliła, ale w istocie powodowałoby usankcjonowanie czynności procesowych podjętych przez osobę, której ustawa nie zezwala ich podejmować ${ }^{11}$.

Należy przy tym uwzględnić, że istnienie w Kodeksie postępowania cywilnego szczególnych regulacji odnośnie do następczego zatwierdzenia czynności procesowych dokonanych bez należytego umocowania wyklucza jakiekolwiek odpowiednie stosowanie przepisów Kodeksu cywilnego dotyczących pełnomocnictwa. Nadto, warto zwrócić uwagę, że czynności procesowe mają zgoła odmienny charakter niż czynności prawne prawa materialnego.

Już tylko na marginesie należy dodać, że dopuszczenie następczego zatwierdzania czynności procesowych mogłoby doprowadzić do sytuacji, w której strona dokonywałaby wyłącznie wybiórczego zatwierdzenia czynności, z pominięciem tych dla niej niekorzystnych. To z kolei wpłynęłoby na omijanie przepisów o moż-

10 Uchwała Sądu Najwyższego z dnia 28 lipca 2004 roku, sygn. akt III CZP 32/04, OSNC 2006, nr 1, s. 2.

11 Ibidem. 
liwości uchylania się od skutków prawnych przedsiębranych czynności, wprowadzając nieuzasadniony chaos do toczących się postępowań.

Stanowisko Sądu Najwyższego zaprezentowane w uchwale z dnia 28 lipca 2004 roku zostało częściowo skrytykowane w glosie Zbigniewa Kmiecica ${ }^{12}$. Autor zwrócił w niej uwagę, że zasada dopuszczalności konwalidacji czynności procesowych przez ich potwierdzenie wynika z treści art. 401 pkt 2 k.p.c., a nie z art. 97 k.p.c. Zgodnie $\mathrm{z}$ jego brzmieniem nie można żądać wznowienia postępowania cywilnego, jeżeli przed uprawomocnieniem się orzeczenia nieprawidłowo reprezentowana strona potwierdziła dokonane czynności procesowe. W konsekwencji trudno przyjąć, że intencją ustawodawcy było dopuszczenie swoistej konwalidacji wyłącznie w zakresie wznowienia postępowania, a jej wykluczenie w przypadku postępowania pierwotnego.

Za błędne, zdaniem autora, należy również uznać twierdzenie, jakoby uznanie dopuszczalności konwalidacji czynności procesowych oznaczało przyzwolenie na podejmowanie czynności wbrew zakazowi ustawy. Jak stwierdza on bowiem dalej:

Istota konwalidacji polega na tym, że sanuje ona czynności dokonane wbrew zakazowi ustawy, a tym samym wyłącza możliwość ich unieważnienia bądź konieczność ich powtórzenia, jeżeli nastąpią określone w ustawie okoliczności [...]. Co więcej, instytucję konwalidacji stosuje się wyłącznie w odniesieniu do czynności, dla których podstawę stanowią przepisy o charakterze ius cogens.

Zakwestionowany w przedmiotowej glosie zostaje również argument Sądu Najwyższego, że legalizowanie udziału w procesie w charakterze pełnomocnika podmiotu, który nie może nim być, kreowałoby zagrożenie interesów wymiaru sprawiedliwości. Ograniczając katalog osób uprawnionych do pełnienia funkcji pełnomocnika, ustawodawca kierował się bowiem względami interesu strony oraz ekonomii procesowej, zaś w sytuacji, gdy udział w charakterze pełnomocnika podmiotu nieuprawnionego już się dokonał, a strona nie kwestionuje tak dokonanych czynności, powyższe względy przemawiają za dopuszczeniem możliwości ich zatwierdzenia, bez konieczności powtarzania postępowania, którego wynik najprawdopodobniej będzie taki sam.

Reasumując, zdaniem autora nieuzasadnione jest przyjęcie, że czynności procesowe dokonane przez osobę niemogącą pełnić roli pełnomocnika nie mogą zostać następczo konwalidowane przez osobę uprawnioną. Możliwość ta nie wynika bowiem $\mathrm{z}$ art. 97 k.p.c., ale $\mathrm{z}$ art. 401 pkt 2 k.p.c., i nie ogranicza się wyłącznie do przypadków, w których działający pełnomocnik nie legitymuje się pełnomocnictwem lub przekracza jego zakres.

12 Z. Kmiecic, Glosa do uchwaty SN z dnia 28 lipca 2004 r., III CZP 32/04, „Orzecznictwo Sądów Polskich" 2007, nr 6, s. 69. 
Mimo przytoczonych argumentów glosatora, Sąd Najwyższy podtrzymał swoje stanowisko również w wyroku z dnia 14 czerwca 2005 roku $^{13}$ oraz z dnia 8 maja $2007 \mathrm{roku}^{14}$, stwierdzając, że nienależyte umocowanie pełnomocnika zachodzi zarówno wtedy, gdy osoba działająca jako pełnomocnik nie legitymuje się pełnomocnictwem, jak i wówczas, gdy strona wprawdzie udzieliła takiej osobie pełnomocnictwa, ale osoba ta nie może być w danej sprawie pełnomocnikiem, gdyż nie należy do kręgu osób, które według ustawy mogą być pełnomocnikami. Tak istotne naruszenie nie może być konwalidowane przez następcze zatwierdzenie przez osobę uprawnioną. Po raz kolejny zwrócono również uwagę, że przyjęcie odmiennego poglądu prowadziłoby do obejścia przepisów ustawy.

Zauważając niejednolitość orzecznictwa w zakresie omawianego problemu, Sąd Najwyższy zdecydował się podjąć w dniu 8 lipca 2008 roku uchwałę, w której przyjąl, że występowanie w charakterze pełnomocnika procesowego osoby, która nie może być pełnomocnikiem, oznacza brak należytego umocowania powodujący nieważność postępowania ${ }^{15}$.

W przytoczonym orzeczeniu Sąd Najwyższy zwrócił w pierwszej kolejności uwagę, że: „Art. 87 k.p.c. ma charakter bezwzględnie obowiązujący i nie może być obchodzony ani przez sąd, ani przez strony, a do tego prowadziłoby akceptowanie udziału w postępowaniu osób ustawowo nieupoważnionych do występowania w charakterze pełnomocnika procesowego". Pełnomocnictwo procesowe kształtuje bowiem autonomiczny — względem regulacji Kodeksu cywilnego — stosunek prawny, normowany przepisami prawa procesowego o charakterze bezwzględnie obowiązującym. I bez znaczenia pozostaje w tej sytuacji fakt, że Kodeks cywilny nie zawiera ograniczeń dotyczących kręgu osób mogących być pełnomocnikami. Ograniczenia te bowiem wprowadza Kodeks postępowania cywilnego, stanowiąc, że pełnomocnictwo procesowe jako odrębna instytucja prawna ma zakres węższy w stosunku do pełnomocnictwa udzielonego „na zasadach ogólnych”. W konsekwencji za osobę prawidłowo umocowaną można uważać wyłącznie taką, która została umocowana zgodnie z przepisami Kodeksu postępowania cywilnego (w tym również art. 87 k.p.c.).

Należy przy tym zauważyć, że żadnego wyjątku nie konstytuuje tutaj również art. 97 k.p.c., albowiem na jego podstawie możliwe jest wyłącznie czasowe dopuszczenie osoby, która na razie nie może przedstawić pełnomocnictwa. Osoba, która nie kwalifikuje się do kręgu osób ustanowionych w art. 87 k.p.c., nie może być pełnomocnikiem procesowym nie tylko „na razie”, ale w ogóle. Co więcej,

13 Wyrok Sądu Najwyższego z dnia 14 czerwca 2005 roku, sygn. akt V CK 731/04, LEX nr 177199.

14 Wyrok Sądu Najwyższego z dnia 8 maja 2007 roku, sygn. akt II PK 297/06, LEX nr 259069.

15 Uchwała Sądu Najwyższego z dnia 8 lipca 2008 roku, sygn. akt III CZP 154/07, OSNC 2008, nr 12, s. 133. 
art. 97 k.p.c. stanowi o czynności jednorazowej, a nie działaniu w toku całego postępowania.

Sąd Najwyższy podkreślił przy tym, że sytuacja pełnienia funkcji pełnomocnika przez osobę niemogącą tego robić powinna być wyraźnie odróżniania od przypadków, w których pełnomocnik jest wyłącznie nieprawidłowo umocowany. Osoba, której ustawa nie przyznaje zdolności postulacyjnej, nie może bowiem zostać dopuszczona do działania na jakimkolwiek etapie postępowania; nie może jej na to zezwolić sąd, a także przeszkody tej nie może usunąć wola strony. W konsekwencji brak ten w każdej sytuacji musi być traktowany jako nieusuwalny, gdyż strona nie mogłaby na żadnym etapie postępowania udzielić skutecznie takiej osobie pełnomocnictwa.

Dla rozstrzygnięcia tej kwestii nie ma również znaczenia, czy brak należytej reprezentacji naruszył $\mathrm{w}$ danym postępowaniu interes strony. Podkreślenia wymaga bowiem, że w interesie każdej ze stron jest rozpoznanie sprawy przy zachowaniu wszystkich wymagań procesowych. Na tego typu naruszenie powoływać się może nie tylko strona błędnie reprezentowana, lecz także strona przeciwna ${ }^{16}$.

Zaprezentowane wyżej stanowisko Sądu Najwyższego zostało następnie podtrzymane w postanowieniu Sądu Najwyższego z dnia 13 stycznia 2009 roku $^{17}$.

Argumenty przedstawione przez Sąd Najwyższy w przytoczonej uchwale, podsumowujące dotychczasowy dorobek judykatury w tej kwestii, należy uznać za słuszne. Nie da się bowiem nie zauważyć zasadniczej różnicy pomiędzy występowaniem w sprawie osoby, która zasadniczo mogłaby być pełnomocnikiem, a sytuacją, w której w sprawie działa osoba w ogóle niemogąca pełnić takiej funkcji. Wydaje się, że w tym drugim wypadku dopuszczenie możliwości potwierdzenia dokonanych przez nią czynności procesowych prowadzi do ukonstytuowania obejścia prawa w czystej postaci. Nawet potwierdzenie dokonanych przez nią czynności nie będzie skutkowało możliwością jej wstąpienia do toczącego się postępowania ze względu na brzmienie art. 87 k.p.c. Przedstawione tam wyliczenie ma bowiem charakter zamknięty i stanowi normę o charakterze bezwzględnie obowiązującym. I o ile prawdą jest, że następcze potwierdzenie danego stanu prawnego przez uprawnioną do tego osobę zawsze dotyczy norm ius congens, to zasada ta nie może być rozumiana w sposób zbyt szeroki. W przeciwnym razie znacząco ograniczony zostałby sens ustanawiania tego typu norm, albowiem w swoim charakterze zbliżyłyby się one do norm o charakterze dyspozytywnym. Nie bez znaczenia pozostaje przy tym, że każda ze stron ma prawo wymagać, by postępowanie toczyło się zgodnie z obowiązującymi normami prawnymi, a zatem tak nieprawidłowo umocowany pełnomocnik narusza nie tylko interes

16 Wyrok Sądu Najwyższego z dnia 16 lutego 2012 roku, sygn. akt III CSK 195/11, LEX nr 1162687.

17 Postanowienie Sądu Najwyższego z dnia 13 stycznia 2009 roku, sygn. akt I PZ 37/08, LEX nr 746192. 
strony reprezentowanej, lecz także interes strony przeciwnej. Dopuszczenie zaś możliwości zatwierdzania przedmiotowych czynności prowadziłoby do sytuacji, w której strona przeciwna zostałaby zmuszona do brania udziału w postępowaniu jawnie naruszającym podstawowe zasady kodeksu postępowania cywilnego. Ich przestrzeganie zaś zostało uznane przez ustawodawcę za tak istotne, że ich naruszenie obarczył on najsurowszą z możliwych sankcji, tj. sankcją nieważności. Należy również zgodzić się z Sądem Najwyższym w zakresie, w jakim neguje związek art. 97 k.p.c. z ewentualną możliwością zatwierdzania czynności procesowych przez osobę uprawnioną $\mathrm{w}$ omawianym przypadku. Wyjątek $\mathrm{w}$ nim opisany może być bowiem stosowany wyłącznie do sytuacji jednostkowych, a nie ogółu czynności podejmowanych w sprawie przez pełnomocników. Co więcej, zgodnie $\mathrm{z}$ jego brzmieniem sąd dopuszcza osobę, która w danym momencie nie może przedstawić pełnomocnictwa, a nie która w ogóle nie jest w stanie uczynić zadość temu wymogowi.

Reasumując, jeśli w sprawie w charakterze pełnomocnika brała udział osoba, która nie mogła nim być, sąd II instancji ma obowiązek uchylić wyrok, znieść postępowanie w zakresie dotkniętym nieważnością i przekazać sprawę sądowi I instancji do ponownego rozpoznania.

\section{Występowanie w sprawie nieprawidłowo umocowanego pełnomocnika}

Równie często zdarza się jednak, że osoba działająca w sprawie w charakterze pełnomocnika nie tyle nie może nim być, ile została nieprawidłowo umocowana. Zgodnie zaś z brzmieniem art. 379 pkt 2 k.p.c. nieważność postępowania zachodzi między innymi wtedy, gdy pełnomocnik strony nie był należycie umocowany. $Z$ drugiej jednak strony nie można pominąć treści art. 401 pkt 2 k.p.c., na mocy którego niedozwolone jest żądanie wznowienia postępowania z powodu nieważności, jeżeli strona była nienależycie reprezentowana, ale potwierdziła dokonane czynności procesowe. Dlatego też kluczowe staje się udzielenie odpowiedzi na pytanie, czy dopuszczalne jest następcze konwalidowanie czynności dokonanych przez takiego pełnomocnika również na wcześniejszym etapie postępowania, bez konieczności doprowadzania do jego wznowienia.

Należy dodać, że użyty w treści art. 86 n. k.p.c. termin „pełnomocnictwo” $\mathrm{z}$ jednej strony oznacza pochodzące od mocodawcy umocowanie pełnomocnika do działania w jego imieniu, $\mathrm{z}$ drugiej zaś — dokument stwierdzający to umocowanie. Samo zaś umocowanie może nastąpić w dowolnej formie. Obowiązkiem pełnomocnika procesowego jest jednak zawsze wykazanie swojego umocowania do działania przed sądem odpowiednim dokumentem. Zgodnie bowiem z przepisem art. $89 \S 1$ k.p.c. pełnomocnik obowiązany jest przy pierwszej czynności procesowej dołączyć do akt sprawy pełnomocnictwo (rozumiane jako dokument) 
z podpisem mocodawcy lub jego uwierzytelniony odpis. W konsekwencji przyjmuje się, że choć dokument pełnomocnictwa i jego wydanie nie mają znaczenia konstytutywnego, gdyż taki charakter ma już samo udzielenie umocowania, to jednak jest on niezbędnym dowodem potwierdzającym istnienie umocowania pełnomocnika do działania w imieniu strony i nie może zostać zastąpiony żadnym innym środkiem dowodowym.

W kontekście omawianego problemu warto przytoczyć w pierwszej kolejności postanowienie Sądu Najwyższego z dnia 29 września 1998 roku $^{18}$, w którym wyjaśniono, że strona może jedynie skutecznie zatwierdzić czynności dokonane przez osobę nielegitymującą się jej pełnomocnictwem, ale mogącą być pełnomocnikiem strony w chwili dokonywania czynności. Jako podstawę prawną tych rozważań wskazano art. $97 \S 2 \mathrm{w}$ zw. z art. 87 k.p.c. Pogląd ten został następnie potwierdzony przez Sąd Najwyższy w wyroku z dnia 10 sierpnia 2000 roku $^{19}$, w którym wyraźnie podkreślono, że o nieważności postępowania $\mathrm{w}$ rozumieniu art. 379 pkt 2 k.p.c. nie może być mowy, jeśli w sprawie działała osoba spełniająca wymogi z art. 87 k.p.c., której czynności procesowe zaakceptowała następnie osoba uprawniona.

Odmienne stanowisko zajął natomiast Sąd Najwyższy w wyroku z dnia 20 sierpnia 2001 roku, w którym stwierdził, że występowanie w sprawie zarówno osoby niemogącej pełnić funkcji pełnomocnika, jak i takiej, która została wyłącznie źle umocowana, zawsze prowadzi do nieważności postępowania i nie podlega konwalidacji. Zdaniem Sądu Najwyższego to ustawodawca racjonalnie uznał, że brak należytego pełnomocnictwa prowadzi (zawsze) do nieważności postępowania. Jak wyjaśnił zaś w uzasadnieniu: „Udzielenie pełnomocnictwa i udział w tym charakterze określonej osoby nie wyraża się tylko w konkretnych czynnościach procesowych, ale też wpływa w ogólności na przyjętą przez stronę postawę w procesie, rodzaj zgłaszanych zarzutów, sposób dowodzenia stanu faktycznego, itd.” Pogląd ten należy jednak uznać za odosobniony.

Omawiany problem został również poruszony w uchwale Sądu Najwyższego z dnia 8 lipca 2004 roku $^{20}$, która choć skupiała się zasadniczo na kwestii występowania $\mathrm{w}$ sprawie osoby niemogącej w ogóle pełnić funkcji pełnomocnika, to zwróciła również uwagę na brzmienie art. 401 pkt 2 k.p.c. W jej uzasadnieniu Sąd Najwyższy zwrócił uwagę, że zdecydowanie odmiennie należy traktować sytuację, w której za stronę działa pełnomocnik, który wprawdzie jest nienależycie umocowany, ale co do zasady mógłby pełnić tę funkcję. Dalej stwierdził, że:

18 Postanowienie Sądu Najwyższego z dnia 29 września 1998 roku, sygn. akt II CKN 529/98, LEX nr 1214908.

19 Wyrok Sądu Najwyższego z dnia 10 sierpnia 2000 roku, sygn. akt IV CKN 1137/00, LEX nr 530702.

${ }^{20}$ Uchwała Sądu Najwyższego z dnia 28 lipca 2004 roku, sygn. akt III CZP 32/04, OSNC 2006, nr 1, s. 2 . 
Szczególnym przepisem przewidującym zatwierdzenie przez stronę czynności procesowych podjętych w imieniu tej strony przez osobę, która nie została należycie umocowana, jest art. $97 \S 2$ k.p.c. Przepis ten jest kontynuacją i rozwinięciem unormowania zawartego w $\S 1$ tego artykułu. Przewidziane w nim zatwierdzenie przez stronę dotyczy tylko „dopuszczonej tymczasowo przez sąd”, „naglącej” czynności procesowej „po wniesieniu pozwu”, podjętej przez osobę nie mogącą „na razie” przedstawić pełnomocnictwa. [...] Wprawdzie w art. 97 k.p.c. unormowana została sytuacja procesowa ściśle określona w tym przepisie, ale ze względu na to, czego ona dotyczy, przepis ten, w związku z art. $70 \S 2$ i art. 401 pkt 2 k.p.c., pozwala na sformułowanie zasady ogólnej, że strona może potwierdzić czynność procesową dokonaną przez osobę, która nie legitymowała się pełnomocnictwem udzielonym jej przez tę stronę.

Odmienność sytuacji, w której w sprawie występuje osoba niemogąca być pełnomocnikiem oraz osoba wyłącznie źle umocowana, podkreślił ponownie Sąd Najwyższy w uchwale z dnia 23 stycznia 2009 roku ${ }^{21}$. Zwrócił uwagę, że przedstawione zagadnienie wymaga uwzględnienia treści art. $97 \S 2$ k.p.c., art. 379 pkt 2 k.p.c. oraz art. 401 pkt 2 k.p.c. Wykluczył jednak możliwość konwalidowania czynności nieprawidłowo umocowanego pełnomocnika na podstawie art. $97 \S 2$ k.p.c. Zważył bowiem, że dotyczy on sytuacji, w której sąd z góry wie o braku pełnomocnictwa i tymczasowo dopuszcza do udziału w sprawie osobę występującą w charakterze pełnomocnika, uzależniając jednak skuteczność dokonanych czynności procesowych od złożenia w zakreślonym terminie pełnomocnictwa lub potwierdzenia tych czynności przez stronę. Następnie stwierdził, że możliwość konwalidacji czynności procesowych dokonanych przez przedmiotowego pełnomocnika nie może być również wywodzona wprost z treści art. 379 pkt 2 k.p.c. Taki wniosek jest jednak uzasadniony w świetle art. 401 pkt 2 k.p.c., albowiem wyklucza wznowienie postępowania, gdy strona przed uprawomocnieniem się wyroku potwierdziła dokonane czynności procesowe. Dlatego też jeśli strona skorzysta z możliwości potwierdzenia dokonanych już w jej imieniu czynności procesowych, przyczyna nieważności, o której mowa w art. 379 pkt 2 k.p.c., zostaje usunięta ze skutkiem ex tunc, co powoduje brak podstaw do uchylenia wydanego w sprawie wyroku na podstawie art. $386 \S 2$ k.p.c., a gdy wyrok się uprawomocni - brak podstaw do wznowienia postępowania (art. 401 pkt 2 in fine k.p.c.). Sąd Najwyższy zaznaczył przy tym, że zasada ta dotyczy wszystkich czynności procesowych dokonanych przez pełnomocnika procesowego działającego bez należytego umocowania, nie wyłączając środków odwoławczych, o ile nie są one obwarowane przymusem adwokacko-radcowskim.

Wedle dominującego poglądu Sądu Najwyższego o nieważności postępowania sądowego z udziałem osoby, która wprawdzie może być pełnomocnikiem, ale nie przedłożyła stosownych dokumentów, może być mowa wyłącznie w sytuacji, gdy uprzednio została ona wezwana do uzupełnienia tego braku w trybie art. 130

21 Uchwała Sądu Najwyższego z dnia 23 stycznia 2009 roku, sygn. akt III CZP 118/08, OSNC 2009, nr 6, s. 76. 
$\S 1$ k.p.c. i nie usunęła go w wyznaczonym terminie ${ }^{22}$. Wątek ten został szerzej omówiony w uzasadnieniu do wyroku Sądu Najwyższego z dnia 6 kwietnia 2011 roku, w którym stwierdzono, że o nieważności postępowania nie decyduje dochowanie reżimu $z$ art. $89 \S 1$ k.p.c., lecz sam fakt udzielenia pełnomocnictwa. Brak ten może jednak zostać usunięty wyłącznie do czasu prawomocnego zakończenia postępowania, a zatem nie w postępowaniu kasacyjnym. Innymi słowy, o swoistej „warunkowej nieważności” postępowania może być mowa wyłącznie do czasu uprawomocnienia się wyroku.

Powyższe stanowisko Sąd Najwyższy podtrzymał jeszcze raz w postanowieniu z 31 stycznia tego samego roku ${ }^{23}$, stwierdzając, że strona przed uprawomocnieniem się wyroku może następczo potwierdzić dokonane czynności procesowe. W sytuacji, w której strona skorzysta z takiej możliwości, przyczyna nieważności, o której jest mowa w art. 379 pkt 2 k.p.c., zostaje usunięta ze skutkiem ex tunc, co powoduje brak podstaw do uchylenia wydanego w sprawie wyroku na podstawie art. $386 \S 2$ k.p.c.

\section{Osoby uprawnione do podnoszenia zarzutu naruszenia art. 379 pkt 2 k.p.c.}

Na zakończenie rozważań warto zastanowić się jeszcze, kto ma prawo podnosić zaistnienie nieważności postępowania, o której mowa w art. 379 pkt 2 k.p.c. Prima facie wydawać by się mogło, że brak właściwiej reprezentacji narusza wyłącznie interes jednej ze stron postępowania, a zatem tylko ona winna mieć prawo powoływania się na to uchybienie.

Takie stanowisko początkowo zaaprobował Sąd Najwyższy, który w wyroku z dnia 21 grudnia 2000 roku $^{24}$ stwierdził, że wymóg należytego umocowania pełnomocnika procesowego ustanowiony jest w interesie tej strony, która korzysta $\mathrm{z}$ jego usług. W konsekwencji tylko ta strona może powołać się na nieważność postępowania z powodu nieprawidłowości w udzieleniu pełnomocnictwa i tylko na jej korzyść zarzut ten podlega rozważeniu przez sąd z urzędu. Druga strona postępowania może zaś przywołać wspomniane naruszenie wyłącznie jako „klasyczne" naruszenie prawa procesowego, co jednak obliguje ją do wykazania, że mogło ono mieć istotny wpływ na wynik sprawy. To stanowisko zostało również

22 Postanowienie Sądu Najwyższego z dnia 9 lipca 2009 roku, sygn. akt III CZP 19/09, LEX nr 512985, tak też Wyrok Sądu Najwyższego z dnia 4 marca 2016 roku, sygn. akt i CSK 218/15, LEX nr 2015118.

23 Postanowienie Sądu Najwyższego z dnia 31 stycznia 2017 roku, sygn. akt II UZ72/16, LEX nr 2241395.

24 Wyrok Sądu Najwyższego z dnia 21 grudnia 2000 roku, sygn. akt IV CKN 209/00, LEX nr 707911. 
podtrzymane przez Sąd Najwyższy w wyroku z dnia 7 kwietnia 2004 roku $^{25}$, kiedy po raz kolejny podkreślono, że z pozbawienia możliwości należytej obrony swych praw konsekwencje wywodzić może wyłącznie strona w ten sposób poszkodowana.

Powyższy pogląd, choć początkowo jednolity w orzecznictwie Sądu Najwyższego, obecnie należy uznać za nieaktualny. Już bowiem w wyroku z dnia 13 lutego 2004 roku Sąd Najwyższy zwrócił uwagę, że zarzut ten winien być brany pod uwagę przez każdy sąd z urzędu, a zatem nie ma podstaw, dla których uchybienie to nie może zostać wskazane w środku odwoławczym pochodzącym od strony przeciwnej. W kolejnym zaś wyroku — z 23 marca 2006 roku $^{26}$ — Sąd Najwyższy dodał jeszcze, że powoływanie zarzutów procesowych nie może zostać ograniczone przy tak poważnych i rażących naruszeniach, jak te wymienione w art. 379 k.p.c. Takich naruszeń nie można bowiem wartościować, gdyż skutkują one nieważnością z mocy prawa, niezależnie od ich wpływu na przebieg postępowania czy też wynik sprawy ${ }^{27}$. Obie strony mają przy tym interes prawny w tym, by ich sprawa została rozpatrzona przy zachowaniu wszelkich wymogów proceduralnych. Nie można również zapominać, że przestrzeganie rygorów i sankcji procesowych ma wydźwięk ogólny — służy nie tylko interesom stron, lecz także interesowi wymiaru sprawiedliwości. Co więcej, Sąd Najwyższy jako sąd kasacyjny jest zobligowany do badania takich nieprawidłowości z urzędu.

$\mathrm{Na}$ marginesie należy jeszcze dodać, że w postępowaniu kasacyjnym strony bezpośrednio mogą podnosić jedynie zarzut nieważności postępowania przed sądem II instancji. Do badania wyłącznie tej przesłanki zobowiązany jest Sąd Najwyższy z urzędu. Jeśli chodzi zaś o nieprawidłowości dotyczące postępowania sądu I instancji, konieczne jest podniesienie zarzutu naruszenia przez sąd odwoławczy art. $378 \S 1$ k.p.c. lub art. $386 \S 2$ k.p.c., z tym jednak zastrzeżeniem, że takie naruszenie doprowadzi do nieważności postępowania wyłącznie w sytuacji, gdy będzie ono miało istotny wpływ na wynik sprawy.

\section{Podsumowanie}

Omawiane zagadnienie w judykaturze Sądu Najwyższego charakteryzowało się dużymi rozbieżnościami i ulegało licznym modyfikacjom. Dopiero ostatnie lata doprowadziły do ukształtowania w miarę jednolitego stanowiska w tym za-

25 Wyrok Sądu Najwyższego z dnia 7 kwietnia 2004 roku, sygn. akt IV CK 661/03, LEX nr 500178; tak też wyrok Sądu Najwyższego z dnia 9 marca 2005 roku, sygn. akt III CK 263/04, LEX nr 500177.

26 Wyrok Sądu Najwyższego z dnia 23 marca 2006 roku, sygn. akt IV CSK 115/05, LEX nr 182902; tak też wyrok Sądu Najwyższego z dnia 7 listopada 2006 roku, sygn. akt I CSK 224/06, LEX nr 276251.

27 Wyrok Sądu Najwyższego z dnia 11 grudnia 2006 roku, sygn. akt I PK 124/06, OSNP 2008, nr 3-4, s. 27. 
kresie. Mając jednak na uwadze liczbę orzeczeń poruszających ten temat, wydaje się, że w praktyce nadal budzi on pewne wątpliwości.

Należy podkreślić, że nie można utożsamiać z sobą sytuacji procesowych, w których w postępowaniu w roli pełnomocnika występuje osoba w ogóle niemogąca pełnić tej funkcji oraz taka, która jedynie legitymuje się nieprawidłowym umocowaniem. Niezależnie bowiem od niejednoznacznych sformułowań art. 379 pkt 2 k.p.c. oraz art. 401 pkt 2 k.p.c. nie można zapominać o treści art. 87 k.p.c.

Udział w sprawie osoby, która w ogóle nie może pełnić funkcji pełnomocnika, prowadzi do bezwzględnej nieważności postępowania, która winna być brana przez sąd pod rozwagę z urzędu i skutkować wydaniem kasatoryjnego orzeczenia na każdym etapie postępowania. Za taką koncepcją przemawia przede wszystkim to, że zatwierdzenie działań takiej osoby nie doprowadzi w żadnym przypadku do „uzdrowienia” braku jej umocowania. Przedstawione w art. 87 k.p.c. wyliczenie ma bowiem charakter zamknięty i jest normą bezwzględnie obowiązującą, której nie można przeciwstawiać uregulowań dotyczących stosunku pełnomocnictwa z Kodeksu cywilnego. Należy również przychylić się do stanowiska, że każda inna wykładnia prowadziłaby do jaskrawego obejścia prawa, albowiem czyniłaby art. 87 k.p.c. absolutnie iluzorycznym. Niedopuszczalne jest również odwołanie się do treści art. 97 k.p.c., ponieważ dotyczy on sytuacji, w których stawająca w roli pełnomocnika osoba co do zasady może pełnić tę funkcję, a przedstawienie w danej sprawie dokumentu pełnomocnika jest wyłącznie swoistą formalnością. Osoba niemogąca w ogóle pełnić takiej roli nigdy nie będzie w stanie sprostać temu wymogowi.

Zgoła odmiennie winna być natomiast oceniania sytuacja, w której w sprawie działa nieprawidłowo umocowany pełnomocnik. Wykluczenie możliwości następczego zatwierdzenia dokonanych przez niego czynności należy uznać za nadmierny formalizm, który prowadziłby wyłącznie do zbędnego wydłużenia postępowania. W takiej sytuacji bowiem nie dochodzi do konwalidowania przez osobę uprawnioną stanu sprzecznego z prawem.

Należy przy tym jednak podkreślić, że również w tej sytuacji podstawy prawnej nie należy upatrywać w art. 97 k.p.c., albowiem dotyczy on wyłącznie sytuacji wyjątkowych i przejściowych, w których sąd zdaje sobie sprawę, że staje przed nim pełnomocnik nieposiadający umocowania. Uzasadnieniem przyjęcia takiej interpretacji jest zaś przede wszystkim treść art. 401 pkt 2 k.p.c., zgodnie z którą wykluczone jest wznowienie postępowania, jeśli osoba uprawniona potwierdziła dokonane w jej imieniu czynności procesowe. W kontekście brzmienia tego przepisu za niecelowe należy uznać wykluczenie takiej możliwości również na wcześniejszych etapach postępowania. Byłoby to wbrew wszelkiej ekonomii procesowej. Granicę dla dopuszczalności takiej konwalidacji winno stanowić dopiero prawomocne zakończenie postępowania. W konsekwencji stwierdzenie takiego uchybienia przez sąd na etapie postępowania kasacyjnego musi zawsze prowadzić do uchylenia orzeczenia. 
Wreszcie trzeba zaznaczyć, że nieważność z powodu działania w sprawie nienależycie umocowanego pełnomocnika może być podnoszona przez każdą ze stron postępowania. Należy bowiem zgodzić się, że w interesie prawnym każdej ze stron leży procedowanie zgodnie z obowiązującym porządkiem prawnym. Niewątpliwie zaś prowadzące do nieważności całego postępowania naruszenia, które sąd winien brać pod rozwagę z urzędu, stanowią swoisty trzon, którego respektowania może domagać się każdy zainteresowany.

\section{Bibliografia}

Kmiecic Z., Glosa do uchwaty SN z dnia 28 lipca 2004 r., III CZP 32/04, „Orzecznictwo Sądów Polskich" 2007, nr 6, s. 69.

Kodeks postępowania cywilnego. Komentarz, t. 1. Postępowanie rozpoznawcze, red. T. Ereciński, Warszawa 2016.

\section{Akty prawne}

Ustawa z dnia 17 listopada 1964 roku — Kodeks postępowania cywilnego (tekst jedn. Dz.U. z 2016 r. poz. 1822).

\section{Orzecznictwo}

Postanowienie Sądu Najwyższego z dnia 18 marca 2003 roku, sygn. akt IV CKN 1856/00, Lex nr 109422.

Postanowienie Sądu Najwyższego z dnia 13 stycznia 2009 roku, sygn. akt I PZ 37/08, LEX nr 746192.

Postanowienie Sądu Najwyższego z dnia 9 lipca 2009 roku, sygn. akt III CZP 19/09, LEX nr 512985.

Postanowienie Sądu Najwyższego z dnia 31 stycznia 2017 roku, sygn. akt II UZ72/16, LEX nr 2241395.

Uchwała Sądu Najwyższego z dnia 20 grudnia 1968 roku, sygn. akt III CZP 93/68, OSNC 1969, nr 7-8, s. 129.

Uchwała Sądu Najwyższego z dnia 18 września 1992 roku, sygn. akt III CZP 112/92, OSNC 1993, nr 5, s. 75.

Uchwała Sądu Najwyższego z dnia 28 lipca 2004 roku, sygn. akt III CZP 32/04, OSNC 2006, nr 1, s. 2.

Uchwała Sądu Najwyższego z dnia 8 lipca 2008 roku, sygn. akt III CZP 154/07, OSNC 2008, nr 12, str. 133.

Uchwała Sądu Najwyższego z dnia 23 stycznia 2009 roku, sygn. akt III CZP 118/08, OSNC 2009, nr 6, s. 76.

Wyrok Sądu Najwyższego z dnia 24 sierpnia 1937 roku, sygn. akt C I 2382/36, Zb. Urz. 1938, poz. 282.

Wyrok Sądu Najwyższego z dnia 13 marca 1991 roku, sygn. akt I CR 484/90, OSNC 1992, nr 7-8, s. 138.

Wyrok Sądu Najwyższego z dnia 29 września 1998 roku, sygn. akt II CKN 529/98, LEX nr 1214908. Wyrok Sądu Najwyższego z dnia 10 sierpnia 2000 roku, sygn. akt IV CKN 1137/00, LEX nr 530702. Wyrok Sądu Najwyższego z dnia 21 grudnia 2000 roku, sygn. akt IV CKN 209/00, LEX nr 707911. Wyrok Sądu Najwyższego z dnia 20 sierpnia 2001 roku, sygn. akt I PKN 586/00, OSNP 2003, nr 14, s. 335.

Wyrok Sądu Najwyższego z dnia 7 kwietnia 2004 roku, sygn. akt IV CK 661/03, LEX nr 500178. Wyrok Sądu Najwyższego z dnia 9 marca 2005 roku, sygn. akt III CK 263/04, LEX nr 500177. Wyrok Sądu Najwyższego z dnia 14 czerwca 2005 roku, sygn. akt V CK 731/04, LEX nr 177199. 
Wyrok Sądu Najwyższego z dnia 23 marca 2006 roku, sygn. akt IV CSK 115/05, LEX nr 182902. Wyrok Sądu Najwyższego z dnia 7 listopada 2006 roku, sygn. akt I CSK 224/06, LEX nr 276251. Wyrok Sądu Najwyższego z dnia 11 grudnia 2006 roku, sygn. akt I PK 124/06, OSNP 2008, nr 3-4, s. 27.

Wyrok Sądu Najwyższego z dnia 8 maja 2007 roku, sygn. akt II PK 297/06, LEX nr 259069. Wyrok Sądu Najwyższego z dnia 16 lutego 2012 roku, sygn. akt III CSK 195/11, LEX nr 1162687. Wyrok Sądu Najwyższego z dnia 4 marca 2016 roku, sygn. akt i CSK 218/15, LEX nr 2015118.

\section{The nullity of the proceeding in case of representative improperly empowered}

\section{Summary}

The issue discussed, in the jurisprudence of the Supreme Court, has been noted by a large discrepancies and has been the subject of numerous modifications. Only the last years have led to more less unified opinion in the matter concerned.

Participation in the case of a person who is not permitted to act as a proxy leads to the absolute nullity of a procedure and it should be taken under consideration by the court on its own and to result in the annulment of a decision at each step of a procedure. For such a concept appeals the fact that approval of the activities performed by such a person does not lead in any way „to cure" its missing authorization - having considered what listed in the Article 87 of the Polish Code of Civil Procedure it is closed and absolutely binding standard.

While quite differently should be assessed the situation in which improperly empowered representative acts. To exclude the possibility of a subsequent approval of the performed activities should be considered excessive formalism, leading only to unnecessary prolongation of the procedure.

Justification for this interpretation is first of all the content of the Article 401 of the Polish Code of Civil Procedure, according to which the revision is excluded if a person entitled confirmed the procedural actions performed on its behalf. Therefore, in the context of the wording of this provision it should be considered pointless to exclude such a possibility also in the earlier stages of the proceedings. The final disposal of the proceedings should be the only limit for the admissibility of such a rectification.

Finally, it is to be underlined that nullity due to the action of improperly authorized representative it might be raised by any of the parties involved; since that proceedings in compliance with law and rules in force it is each party legal interest. 